\title{
Impact of Training, Job Rotation and Managerial Coaching on Employee Commitment in Context of Banking Sector
}

\author{
Muhammad Rashid Yousaf ${ }^{1}$, Khalid Jamil ${ }^{2}$, Muhammad Roman ${ }^{3}$, Muhammad \\ Shabbir $\mathrm{Ch}^{4}$, Anum Shahid ${ }^{1}$
}

\begin{abstract}
:
This study investigated the impact of training, job rotation, and managerial coaching on employee commitment in the banking sectors of Faisalabad, Pakistan. Employee training is an essential element for the success of an organization to achieve its goals. Training helps the organizations in building a more productive and committed workforce. By providing opportunities for individual employees to grow professionally, training programs i.e. job rotation and managerial coaching can thus foster greater employee commitment. The data for this research was gathered through the use of closeended questionnaire that is designed in a Likert scale format. Based on the convenience sampling method 273 participants participated in survey. Statistical package for social sciences (SPSS) was used for analyzing the data. Results obtained reveal that the training, job rotation and managerial coaching given to the employees in banking sectors of Faisalabad, Pakistan improves their commitment. At last, recommendations are also given for future research studies.
\end{abstract}

Keywords: Training, Job rotation, Managerial coaching, Employee commitment, Turnover

JEL Classification: G21, J53, J63, M14, M53

\section{Introduction}

Banking sectors are the most integral part of the financial services offered in Pakistan. To earn profit banking sectors are competing with each other. For this purpose, commitment of employees is of great importance that affects the performance of

${ }^{1}$ Lecturer School of Business Management, NFC Institute of Engineering and Fertilizer Research, Faisalabad

${ }^{2}$ Ph.D Scholar North China Electric Power University, Beijing, China

${ }^{3}$ Assistant Professor Department of Sociology University of Jhang, Pakistan

${ }^{4}$ Assistant Professor, Department of Sociology Government College University Faisalabad Corresponding Author: khalidjamil29@yahoo.com

6 OCCESS This work is Licensed under a Creative Commons Attribution-Noncommercial 4.0 International License (i) (2)


Muhammad Rashid Yousaf et al. Impact of Training, Job Rotation and Managerial Coaching on Employee Commitment in Context of Banking Sector

employee (Eriksson et al., 2006). The changing nature of workplace environment due to technological advancement cause many challenges for the organizations to remain competent, and develop knowledgeable and committed employees for achievement of organizational goals (Zahra et al., 2014). Employee commitment is considered as the most important issue in organizations today because it reduces negative behavior, such as absenteeism, lateness and turnover. Therefore, organizations should know all those factors that play important role or that have a huge impact in enhancing the commitment of its employees (Irefin et al., 2014). Organizations that find it difficult to retain their skilled employees also find it hard to optimize performance. So, the higher performance of employees in any organization depends upon the investment that organization does in creating their employees committed (Shahid et al., 2013).

Training is a form of investment in which organization invests in their employees to upgrade their skills, knowledge, competencies that help in performing the various task (Alamri et al., 2017). Training improves the effectiveness of organization by enhancing the commitment of employees towards their job. Almost every business is providing training to its employees according to their business needs (Anitha et al., 2016). Training need analysis can be done through various methods like surveys, questionnaires, observations that helps to point out areas that need training. (Zahra et al., 2014). Implementation of training programs for the development of employees will increase the employees loyalty and commitment towards the organization (Nkosi, 2015). Therefore, it is important to identify training methods that encourage allocation of learning among employees in order to achieve greater training impact (Martin, 2010). Job rotation is one of the training method, to get the desired performance among employees that helps in their personal growth as well as in the self-development, which result into the business success (Zehra, 2015). Job rotation is considered as the strongest approach to improve the employee commitment by reducing the boredom and increasing the employee interest in job (Arasi et al., 2016). Another way to keep the employees more committed to an organization is managerial coaching (Kalkavan et al., 2014). Managerial coaching takes place in the workplace as part of the day-to-day interactions between manager and employees (Matsuo et al., 2017). Today's manager shows different behavior towards their employee such as guiding, supporting, and developing them rather than traditional management that exhibits behavior like ordering and controlling the subordinates (Raza et al., 2017).

Thus, to support the development of workforces, managers are required to act as educators. In this context, application of training programs i.e. job rotation and managerial coaching positively affect the commitment of employees. Framework of the study is supported by reciprocity theory, which states that when company helps employees, they may view it having a "sense of debt" towards the organization. So, they will help the company in return. Research on this component of commitment indicates that training can play a vital role in building a sense of debt to the company. Where training that achieves reciprocity in the employee will encourage an employee commitment to the organization (Brum, 2007). The purpose of the study is to investigate the impact of training, job rotation and managerial coaching on employee commitment in banking sectors of Faisalabad, Pakistan.

Sukkur IBA Journal of Management and Business - SIJMB | Vol 7 No. 2 July - December 2020 @ Sukkur IBA University 
Muhammad Rashid Yousaf et al. Impact of Training, Job Rotation and Managerial Coaching on Employee Commitment in Context of Banking Sector

Employers often experience frustration when their highly-rated employees fail to meet their expectations, resign or leave the organization. This creates a problem that management still struggles to understand, identify, and even prevent. As one preemptive measure, some managers have begun to retain and motivate their staff through proactive implementation of human resource (HR) practices and fair compensation policies. Employee commitment is a crucial factor for the organization's success since a company expends tremendous money and resources on its staff. Employees with low degree of commitment reduce the overall morale of an organization. They do not deliberately work for the mission of the organization. They only care about their own success rather than the success of the organization as a whole. Employees with low level of commitment also consider themselves as an outsider not as a long-term member of the company. If they get any attractive job offer, it will result in their departure.

Employee training can lead to the development of a number of professional skills, knowledge, and competencies which are crucial for an employee to perform specific tasks within their workplaces. Hence managers should consider training as an essential tool that helps in building a committed workforce. This study overall determines that if employees get the desired level of skills through training, in return employees consider its obligation to provide beneficial behaviors through performance towards the organization and its members. This study also recommends that using two types of training methods namely managerial coaching and job rotation, mangers can identify how to add flexibility to their employees' tasks and address their weaknesses. Through these two types of training methods not only the commitment of employees increases, but it will also lead to high performance, productivity, and potential market share.

\section{Literature Review}

\section{Training}

It is very important for any organization to have an understanding about workplace training; different researchers have done research in this field. The term "Training" is defined as the process that enhance the knowledge, skills and abilities of the employees that are needed to perform specific job within an organization (Jha, 2016). Training is not limited to training an employee once and its over but training is about continuously enhance the skills of employee with respect to the change so that he could perform well in such a change. (Imran et al., 2015). In the current business environment, training is considered as the most important factor because it not only helps in building the organization effectiveness but also helps in developing the employees. Employee performance may be depends upon many factors but the most important one is "Training" (Falka, 2015). Training itself, however, will do little to enhance the performance of organization and employees unless whatever they learned in training is transferred into their on-the-job behavior (Kasim et al., 2011). Different training techniques are used by trainer to communicate information, skills, knowledge and attitude to trainee. These training techniques can take the form of on the job training or off the job training; in the organization or outside the organization (Obenge et al., 2014).

Sukkur IBA Journal of Management and Business - SIJMB | Vol 7 No. 2 July - December 2020 @ Sukkur IBA University 
Muhammad Rashid Yousaf et al. Impact of Training, Job Rotation and Managerial Coaching on Employee Commitment in Context of Banking Sector

(pp. 60-72)

But in this study, on the job training technique that includes job rotation and managerial coaching are discussed since both of these techniques are favored more and considered more effective in Pakistan.

\section{Job Rotation}

Job rotation is defined as assigning number of tasks to the employees, by shifting their position from one place to another through planned intervals (Zehra, 2015). When employees move from one position to another it results into flexibility, new experience, new skills, new professional fields, reduce boredom by working in same position for long periods of time, boost morale and motivation among employees (Saravani et al., 2013). Job rotation also allows employee to broaden their perspective by gaining experience in multiple jobs (Adjei, 2012). Job rotation can also be used as a learning tool. It does not involve learning only on the part of the employee i.e. acquiring skills and thus becoming more versatile, but also learning on the part of the organization that is to learn about employee's strengths and abilities which helps in facilitating employee development (Wagner et al., 2017). Employees get familiar with the various facets of the firm operations. Such situation adds flexibility among employees by making them well-informed with the entire work process (Nwaeke, 2014). Another major contribution of job rotation is not only to eliminate the problems employ face in a specific job they are performing but also to reduce the level of complaints and protests to work conditions (Omer et al., 2017). While applying the job rotation, organizations must take into account that their main focus should be on the quality of employ work experience rather than quantity of work. And the next rotation plan should be based on the learning capability and adjustment time of the employees (Mohan et al., 2015).

\section{Managerial Coaching}

Managerial coaching is a form of coaching and is defined as coaching that is provided by a manager or supervisor who serves as a facilitator of learning (Raza et al., 2017). Being a coach, manager has to performs various tasks such as communicate clearly to subordinates, acknowledge achievement of employees, fair reward system, frequent feedback for improving employee performance, provide various learning opportunities, provide guidance and being a role model for employees (Ali et al., 2018). Managerial coaching is now recognized as one of the most desirable tools for successful management and learning in organizations (Kim et al., 2013). Organizations that implements managerial coaching has a competitive advantage by motivating and empowering employees for better performance and building more committed workforce (David et al., 2013). With the help of coaching, manager not only promotes learning and motivate employees to take ownership, but also help employees to get involve in the organization they work for (McCarthy et al., 2013). Managerial coaching can also be a part of organizational culture, so that managers take advantage of everyday opportunities for development of employees. Different researches showed that manager provide assistance to their employees by mean of counseling (Park et al., 2008). It means that manager behaves more than his official manager and subordinate relation

Sukkur IBA Journal of Management and Business - SIJMB | Vol 7 No. 2 July - December 2020 @ Sukkur IBA University 
Muhammad Rashid Yousaf et al. Impact of Training, Job Rotation and Managerial Coaching on Employee Commitment in Context of Banking Sector

by acting as an ideal manager for its employees by providing them with effective managerial coaching.

\section{Employee Commitment}

Employee commitment is defined as degree to which an employee considers himself as part of organization and continuously wants to contribute in it (Dixit et al., 2012). Employee commitment is a psychological attachment of employee towards the organization, It also influence the decision of employee to be employed by the organization (Andrew, 2017). Commitment benefits both employers and employees. For employees, it creates a positive relationship with organization and enhance their willingness to work. Whereas for employers, it reduces cases of absenteeism, reduce turnover rate and enhance the services (Lee et al., 2013). A committed employee is the one who stands by its organization through thick and thin, protect its assets and work hard to achieve organizational goals (Nayak et al., 2018). Employee commitment is the most important factor in any organization as it affects the intentions of individual to leave the organization, level of absenteeism and organization citizenship behavior (Krajcsak, 2018). 'Highly committed" employees possess more positive attitude towards their work (Brum, 2007). Organization performance is directly related to the commitment of employees. Committed employees perform their jobs better than the expectations of management. Therefore, employee commitment is essential for obtaining high output and sustainable competitive advantage (Gul, 2015).

\section{Methodology}

The primary data is collected for this study. The data was gathered with the help of a structured questionnaire designed in a Likert scale format. The questionnaire comprises of 36 closed-ended questions based on each variable to be tested in this study.

To measure the impact of training researchers adopted the questionnaire from scale of researcher (Krishnendu et al., 2017). It includes 10 questions anchored on 5-point Likert scale. To measure job rotation researcher adopted questionnaire from scale of researcher (Zehra, 2015). It includes 10 questions on a 5-point Likert type scale. To measure the impact of managerial coaching researcher adopted questionnaire from scale of researcher (Ellinger et al., 2003). It includes 8 questions anchored on a seven-point Likert-type scale. To measure employee commitment researcher adopted questionnaire from scale of researcher (Mowday, 1979). It includes 8 questions presented in a 5-point Likert scale format.

Population of the study consists of employees working in banking sectors of Faisalabad, Pakistan. The employees of each Habib bank Limited, Bank Alfalah, Meezan bank and their branches respectively in Faisalabad city are taken as population of the study.

Respondents were selected with the help of convenience sampling technique. The reason for choosing this technique was that responses were collected according to the availability of the respondents. This also helps to gather maximum responses, which help in the final analysis. The sample size is taken as 273. 


\section{Theoretical Framework}

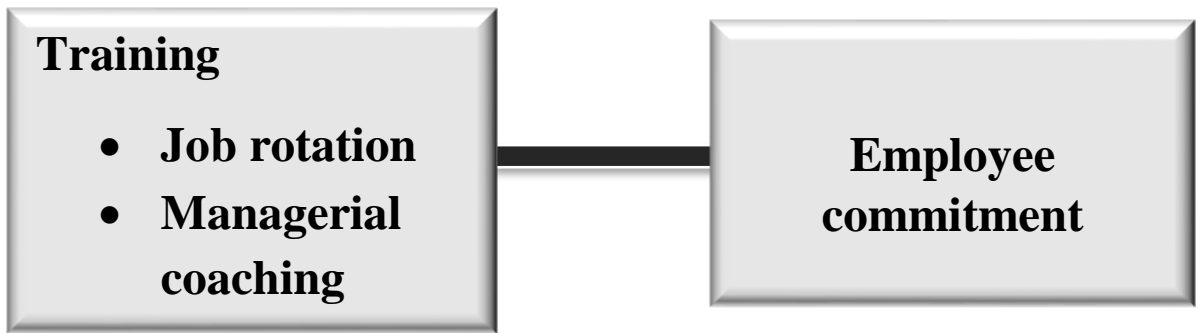

\section{Hypotheses}

H1: There is a significant relationship between training and employee commitment

$\mathrm{H} 2$ : There is a significant relationship between job rotation and employee commitment H3: There is a significant relationship between managerial coaching and employee commitment

\section{Results}

\section{Frequencies of demographic data}

A total of 273 participants responded to the survey. Majority of the respondents were male i.e. $66.3 \%$ and $33.7 \%$ were females participated in the survey.

\section{Gender}

\begin{tabular}{|l|l|l|l|l|}
\hline Gender & Frequency & Percent & Valid percent & Cumulative percent \\
\hline Male & 181 & 66.3 & 66.3 & 66.3 \\
\hline Female & 92 & 33.7 & 33.7 & 100.0 \\
\hline Total & 273 & 100.0 & & \\
\hline
\end{tabular}

The age groups of the participants were as follows: 30-39 years of age (42.1\%), 40-49 years of age (24.5\%), 20-29 years of age (23.8\%), 50 and above $(9.5 \%)$.

Age

\begin{tabular}{|l|l|l|l|l|}
\hline Age & Frequency & Percent & $\begin{array}{l}\text { Valid } \\
\text { percent }\end{array}$ & $\begin{array}{l}\text { Cumulative } \\
\text { percent }\end{array}$ \\
\hline $20-29$ & 65 & 23.8 & 23.8 & 23.8 \\
\hline $30-39$ & 115 & 42.1 & 42.1 & 65.9 \\
\hline $40-49$ & 67 & 24.5 & 24.5 & 90.5 \\
\hline 50 and above & 26 & 9.5 & 9.5 & 100.0 \\
\hline Total & 273 & 100.0 & 100.0 & \\
\hline
\end{tabular}


Muhammad Rashid Yousaf et al. Impact of Training, Job Rotation and Managerial Coaching on Employee Commitment in Context of Banking Sector

Majority of respondents were master's degree holders i.e. $61.9 \%$ whereas, $38.1 \%$ respondents have completed their graduation respectively.

Education

\begin{tabular}{|l|l|l|l|l|}
\hline Education & Frequency & Percent & $\begin{array}{l}\text { Valid } \\
\text { Percent }\end{array}$ & $\begin{array}{l}\text { Cumulative } \\
\text { percent }\end{array}$ \\
\hline Bachelors & 104 & 38.1 & 38.1 & 38.1 \\
\hline Masters & 169 & 61.9 & 61.9 & 100.0 \\
\hline Total & 273 & 100.0 & 100.0 & \\
\hline
\end{tabular}

Majority of respondents were employees of Habib Bank Limited i.e. 45.8\%, Bank Alfalah 31.9\%. Whereas, 22.3\% of respondents were employees of Meezan Bank.

\section{Respondents as per bank}

\begin{tabular}{|l|l|l|l|l|}
\hline Bank & Frequency & Percent & $\begin{array}{l}\text { Valid } \\
\text { percent }\end{array}$ & $\begin{array}{l}\text { Cumulative } \\
\text { percent }\end{array}$ \\
\hline HBL & 125 & 45.8 & 45.8 & 45.8 \\
\hline Bank Alfalah & 87 & 31.9 & 31.9 & 77.7 \\
\hline Meezan Bank & 61 & 22.3 & 22.3 & 100.0 \\
\hline Total & 273 & 100.0 & 100.0 & \\
\hline
\end{tabular}

$32.2 \%$ of the respondents have worked for the banking industry for 6-10 years, 30.8\% respondents for over 10 years. $24.5 \%$ for $2-5$ years and remaining $12.5 \%$ have worked for less than 2 years.

\begin{tabular}{|l|l|l|l|l|}
\hline Experience & Frequency & Percent & $\begin{array}{l}\text { Valid } \\
\text { percent }\end{array}$ & $\begin{array}{l}\text { Cumulative } \\
\text { percent }\end{array}$ \\
\hline $\begin{array}{l}\text { Less than } 2 \\
\text { years }\end{array}$ & 34 & 12.5 & 12.5 & 12.5 \\
\hline 2-5 years & 67 & 24.5 & 24.5 & 37.0 \\
\hline 6-10 years & 88 & 32.2 & 32.2 & 69.2 \\
\hline $\begin{array}{l}\text { Above 10 } \\
\text { years }\end{array}$ & 84 & 30.8 & 30.8 & 100.0 \\
\hline Total & 273 & 100.0 & 100.0 & \\
\hline
\end{tabular}

$33.7 \%$ respondents have income level of 36000-45000. 31.1\% have income level of above 45000 . Whereas, $18.3 \%$ respondents of whole sample have income level in range of 26000-35000 and remaining 16.8 have income level less than or equal to 25000 . 
Muhammad Rashid Yousaf et al. Impact of Training, Job Rotation and Managerial Coaching on Employee Commitment

\begin{tabular}{|l|l|l|l|l|}
\hline \multicolumn{5}{|c|}{ Income } \\
\hline $\begin{array}{l}\text { Income } \\
\text { Less than or equal to }\end{array}$ & Frequency & Percent & $\begin{array}{l}\text { Valid } \\
\text { percent }\end{array}$ & $\begin{array}{l}\text { Cumulative } \\
\text { percent }\end{array}$ \\
\hline 26000 & 160.8 & 16.8 & 16.8 \\
\hline $36000-45000$ & 50 & 18.3 & 18.3 & 35.2 \\
\hline Above 45000 & 92 & 33.7 & 33.7 & 68.9 \\
\hline Total & 85 & 31.1 & 31.1 & 100.0 \\
\hline
\end{tabular}

\section{Reliability Analysis}

\begin{tabular}{|l|l|}
\hline Variables & Cronbach's Alpha Coefficient( $\boldsymbol{\alpha})$ \\
\hline Training & 0.722 \\
\hline Job rotation & 0.701 \\
\hline Managerial coaching & 0.818 \\
\hline Employ commitment & 0.707 \\
\hline
\end{tabular}

The result of reliability analysis of first variable training is 0.722 , second variable job rotation is 0.701 , third variable managerial coaching is 0.818 and fourth variable employee commitment is 0.707 , which are greater than the acceptable value 0.7 and indicates that all the variables are reliable.

\section{Correlation Analysis}

\begin{tabular}{|l|l|l|l|l|l|}
\hline Variables & & $\begin{array}{l}\text { Trainin } \\
\text { g }\end{array}$ & $\begin{array}{l}\text { Job } \\
\text { rotation }\end{array}$ & $\begin{array}{l}\text { Managerial } \\
\text { coaching }\end{array}$ & $\begin{array}{l}\text { Employee } \\
\text { commitment }\end{array}$ \\
\hline Training & $\begin{array}{l}\text { Pearson } \\
\text { correlation } \\
\text { Sig.(2-tailed) } \\
\mathrm{N}\end{array}$ & 1 & & & \\
\hline Job rotation & $\begin{array}{l}\text { Pearson } \\
\text { correlation } \\
\text { Sig.(2-tailed) } \\
\mathrm{N}\end{array}$ & $.494^{* *}$ & 1 & & \\
\hline $\begin{array}{l}\text { Managerial } \\
\text { coaching }\end{array}$ & $\begin{array}{l}\text { Pearson } \\
\text { correlation } \\
\text { Sig.(2-tailed) } \\
\mathrm{N}\end{array}$ & $.424^{* *}$ & $.411^{* *}$ & 1 & \\
\hline $\begin{array}{l}\text { Employee } \\
\text { commitment }\end{array}$ & $\begin{array}{l}\text { Pearson } \\
\text { correlation } \\
\text { Sig.(2-tailed) } \\
\mathrm{N}\end{array}$ & $.596^{* *}$ & $.666^{* *}$ & $.381^{* *}$ & 1 \\
\hline
\end{tabular}

Sukkur IBA Journal of Management and Business - SIJMB | Vol 7 No. 2 July - December 2020 ○ Sukkur IBA University 
$* *$ Correlation is significant at the 0.01 level (2-tailed)

The relationship between training is tested against the employee commitment. The result indicates a strong positive correlation between independent and dependent variable $\left(\mathrm{r}=.596^{* *}, \mathrm{p}\right.$-value $\left.\leq .05\right)$. Similarly, the relationship between job rotation is tested against the employee commitment. The result indicates a strong positive correlation between these variables $\left(\mathrm{r}=.666^{* *}\right.$, $\mathrm{p}$-value $\left.\leq .05\right)$. Pearson coefficient $(\mathrm{r})$ value for relationship between managerial coaching and employee commitment indicates that there exists a moderate correlation between two variables $\left(\mathrm{r}=.381^{* *}\right.$, $\mathrm{p}$ value $\leq .05)$.

\section{Regression Analysis}

\begin{tabular}{|l|l|l|l|}
\hline Dependent variable & \multicolumn{3}{|c|}{ Employee commitment } \\
\hline Independent variables & R square & Beta $(ß)$ & Significance \\
\hline Training & 0.355 & 0.727 & 0.000 \\
\hline Job rotation & 0.444 & 0.993 & 0.000 \\
\hline Managerial coaching & 0.145 & 0.290 & 0.000 \\
\hline
\end{tabular}

The value of R-square 0.355 shows impact of training on employee commitment is almost $36 \%$. where, beta coefficient shows 1-unit change in explanatory variable cause 0.727 change in response variable. R-square value 0.444 shows the impact of job rotation on employee commitment i.e. $44 \%$ and beta coefficient shows 1-unit change in explanatory variable cause 0.993 change in response variable. Similarly, 0.145 value of R-square shows the impact of managerial coaching on employee commitment is almost $15 \%$ where, beta coefficient shows 0.290 -degree change in response variable due to 1 unit change in explanatory variable. Significance value is 0.000 which is less then acceptable value $(<.05)$ shows that regression analysis is significant.

\section{Conclusion}

After the analysis of data, statistical results reflect that employee attitude towards training, job rotation and managerial coaching has been positive and they view training, job rotation and managerial coaching as a source of increased commitment in banking sectors. Regression and correlation analysis showed a significant relationship between independent variables and dependent variable. The results of our analysis proved the hypothesis $\mathrm{H} 1$ that there is a significant relationship between training and employee commitment as the research of (Ajibade, 2014) who states that training does increase employees' commitment to the organization. Second hypothesis H2, there is a significant relationship between job rotation and employee commitment hence proved according to the study of (Mohsan et al., 2012) who states that job rotation has a

Sukkur IBA Journal of Management and Business - SIJMB | Vol 7 No. 2 July - December 2020 @ Sukkur IBA University 
Muhammad Rashid Yousaf et al. Impact of Training, Job Rotation and Managerial Coaching on Employee Commitment in Context of Banking Sector

significant relationship with employee commitment and other outcomes. Third hypothesis $\mathrm{H} 3$, there is a significant relationship between managerial coaching and employee commitment is proved as the research of (Kalkavan et al., 2014) who states that managerial coaching behavior has a positive effect on employee commitment. Thus, in order to remain competitive in today's environment, organizations need to provide excellent training programs i.e. job rotation and managerial coaching to employees. This study will help higher management of banking sector how to retain its employees and which factors are helpful for the commitment of employees.

\section{Limitations and Future Research Directions}

The population of the study consisted of three banking sectors in the Faisalabad, Pakistan. Therefore, the results may not be generalizable to other banks in Faisalabad, Pakistan. Besides, another major limitation is the focus on specific industry, Future research can be done on other public or private sectors. One more significant limitation was the small sample size compared to the large number of employees working in banking sectors in Faisalabad, Pakistan. Future research can be done by considering a vast geographical area and covering other cities of the country in order to increase the population size so that more precise and accurate results can be achieved. Since this study investigated only two dimensions of training on employee commitment i.e. job rotation and managerial coaching. Future studies can focus on other dimensions such as orientation, mentoring, safety training, internship training, and analyze the impact of these factors on employees' commitment, with the aim to improve the overall quality of the results.

\section{References:}

Adjei, D. (2012). The impact of job rotation on employees' performance A case study: Utrak Financial Services Limited.

Ajibade, O. S. (2014). Investigating the effect of training on employees' commitment: An empirical study of a discount house in Nigeria. 11(3), 7-18.

Alamri, \& Al-Duhaim. (2017). Employees Perception of Training and Its Relationship with Organizational Commitment among the Employees Working at Saudi Industrial Development Fund. International Journal of Business Administration $8(2), 25$.

Ali, Lodhi, Aziz, S., \& Raza, B. (2018). Examining the Impact of Managerial Coaching on Employee Job Performance: Mediating Role of Work Engagement, LeaderMember-Exchange Quality, Job Satisfaction, and Turnover Intentions. Pakistan Journal of Commerce Social Sciences 12(1).

Andrew, A. (2017). Employees' Commitment and Its Impact on Organizational Performance.

Anitha, R., \& Kumar, M. A. (2016). A study on the impact of training on employee commitment in the private insurance sector in Coimbatore district. International Journal of Commerce and Management Research, Volume 2(Issue 11).

Sukkur IBA Journal of Management and Business - SIJMB | Vol 7 No. 2 July - December 2020 ๑ Sukkur IBA University 
Muhammad Rashid Yousaf et al. Impact of Training, Job Rotation and Managerial Coaching on Employee Commitment in Context of Banking Sector

Arasi, \& Alizadeh, B. (2016). The relationship between job rotation and duty commitment of employees: A case study among employees of Islamic Azad. International Journal of Organizational Leadership, 87-95.

David, O. A., \& Matu, S. A. (2013). How to tell if managers are good coaches and how to help them improve during adversity? the managerial coaching assessment system and the rational managerial coaching program. Journal of Cognitive Behavioral Psychotherapies13.

Dixit, V., \& Bhati, M. (2012). A study about employee commitment and its impact on sustained productivity in Indian auto-component industry. European journal of business and social sciences, 1(6), 34-51.

Ellinger, A. D., Ellinger, A. E., \& Keller, S. B. (2003). Supervisory coaching behavior, employee satisfaction, and warehouse employee performance: A dyadic perspective in the distribution industry. Human resource development quarterly, 14(4), 435-458.

Eriksson, T., \& Ortega, J. (2006). The adoption of job rotation: Testing the theories. Industrial \& Labor Relations Review, 59(4), 653-666.

Falka, Y. F. (2015). Impact of Training and Development, training design and on the job training onEmployee's commitment in banking sector of Pakistan

International Journal of Business and Management Invention Volume 4 (Issue 11 ).

Gul, Z. (2015). Impact of employee commitment on organizational development. Journal of Social Sciences, 9(2), 117-124.

Imran, M., \& Tanveer, A. (2015). Impact of training \& development on employees' performance in banks of pakistan. European Journal of Training Development Studies 3(1), 22-44.

Irefin, P., \& Mechanic, M. A. (2014). Effect of employee commitment on organizational performance in Coca Cola Nigeria Limited Maiduguri, Borno state. Journal of Humanities Social Science 19(3), 33-41.

Jha, V. (2016). Training and development program and its benefits to employee and organization: A conceptual study. International Journal of Scientific Research in Science Technology 2, 80-86.

Kalkavan, S., \& Katrinli, A. (2014). The effects of managerial coaching behaviors on the employees' perception of job satisfaction, organisational commitment, and job performance: Case study on insurance industry in Turkey. Procedia-Social Behavioral Sciences, 150, 1137-1147.

Kasim, \& Ali, S. (2011). The influence of training design on training transfer performance among support staff of higher education institution in Malaysia. International Journal of Innovation, Management Technology 2(5), 377.

Kim, Egan, W., \& Kim, J. (2013). The impact of managerial coaching behavior on employee work-related reactions. Journal of Business Psychology 28(3), 315330.

Krajcsak, Z. (2018). Relationships between employee commitment and organizational cultures: a theoretical framework. International Journal of Organizational Analysis, 26(3), 398-414.

Sukkur IBA Journal of Management and Business - SIJMB | Vol 7 No. 2 July - December 2020 ๑ Sukkur IBA University 
Muhammad Rashid Yousaf et al. Impact of Training, Job Rotation and Managerial Coaching on Employee Commitment in Context of Banking Sector

Krishnendu, \& ., P. (2017). Importance of Training and Development and its Impact on Employees' of Hotels in Kolkata, India: An empirical study. Journal of Tourism and Hospitality Management, Vol. 5, No. 2,.

Lee, \& Chen. (2013). The relationship between employee commitment and job attitude and its effect on service quality in the tourism industry. American Journal of Industrial and Business Management, 3(02), 196.

Martin, H. J. (2010). Improving training impact through effective follow-up: techniques and their application. Journal of Management Development, 29(6), 520-534.

Matsuo, \& Makoto, T. (2017). The effect of diagnostic and interactive uses of management control systems and managerial coaching on reflection in teams. Journal of accounting organizational change 13(3), 410-424.

McCarthy, G., \& Milner, J. (2013). Managerial coaching: challenges, opportunities and training. Journal of Management Development 32(7), 768-779.

Mohan, K., \& Gomathi. (2015). The effects of job rotation practices on employee development: An empirical study on nurses in the hospitals of vellore district. Mediterranean Journal of Social Sciences, 6(1), 209.

Mohsan, Nawaz, \& Khan, S. (2012). Impact of job rotation on employee motivation, commitment and job involvement in banking sector of Pakistan. African Journal of Business Management, 6(24), 7114-7119.

Nayak, Tanaya, \& Sahoo, P. (2018). Workplace empowerment, quality of work life and employee commitment: a study on Indian healthcare sector. Journal of Asia Business Studies, 12(2), 117-136.

Nkosi, S. M. (2015). Effects of Training on Employee Commitment, Retention and Performance: A Case Study of a Local Municipality in SouthAfrica. European Journal of Business Management 7(15), 104-108.

Nwaeke. (2014). Impact of job rotations and employees'performances in manufacturing companies: Nigeria dr. Austin o. Oparanma, lecturer.

Obenge, P. O., Okibo, W. B. a., Nyang'au, A., Ondieki, S. M., Nyongesa, W. J., \& Nyamasege. (2014). The Effect of Staff Training on the Employee Commitment in the Implementation of Strategic Plans in Public Secondary Schools in Kisii County. International Journal of Business Social Science 5(3).

Omer, \& Al.Beisani. (2017). Job Rotation \& Its Impact on employees' Performance: An Empirical Study among Employees at Red Sea University, Sudan International Journal of Scientific Research and Management (IJSRM) $\|$ Volume $\|5\|(\|$ Issue $\|07\|)$.

Park, S., Yang, B., \& McLean, G. (2008). An Examination of Relationships between Managerial Coaching and Employee Development. Online Submission.

Raza, B., Ali, M., Ahmed, S., \& Moueed, A. (2017). Impact of Managerial Coaching on Employee Performance and Organizational Citizenship Behavior: Intervening Role of Thriving at Work. Pakistan Journal of Commerce Social Sciences 11(3).

Saravani, S. R., \& Abbasi, B. (2013). Investigating the influence of job rotation on performance by considering skill variation and job satisfaction of bank employees. 20(3), 473-478. 
Muhammad Rashid Yousaf et al. Impact of Training, Job Rotation and Managerial Coaching on Employee Commitment in Context of Banking Sector (рp. 60-72)

Shahid, A., \& Azhar, S. M. (2013). Gaining employee commitment: Linking to organizational effectiveness. Journal of Management Research 5(1), 250-268.

Wagner, Mann, R., \& Mohammad, M. (2017). High task interdependence: job rotation and other approaches for overcoming ingroup favoritism. Journal of Manufacturing Technology Management, 28(4), 485-505.

Zahra, S., Iram, A., \& Naeem, H. (2014). Employee training and its effect on employees' job motivation and commitment: Developing and proposing a conceptual model. Journal of Business Management 16(9), 60-68.

Zehra, N. (2015). Impact of Job Rotation on Employee Performance: The Case of Pakistani Banking Industry. Journal of Social Sciencess Business Management 2(2), 01-12. 